\title{
APPLICATION OF SIMPLE PARAMAGNETIC SUSCEPTIBILITY TO RAPID DISCRIMINATION OF ILMENITE COMPOSITIONS IN EXPLORATION FOR KIMBERLITE IN THE COLORADO - WYOMING PROVINCE, USA.
}

Vos, W.P. and McCallum, M.E.

Dept. of Earth Resources, Colorado State University, Fort Collins, CO 80523 USA.

Magnesium-rich ilmenite (picroilmenite) is one of the most characteristic minerals of kimberlite rocks, but its recognition in concentrates recovered during exploration programs may be complicated by the presence of significant quantities of non-kimberlitic ilmenite $(\mathrm{e} . \mathrm{g}$. ferroilmenite from gabbro-anorthosite, manganoilmenite from granitic rocks or carbonatite). The possibility of separation based on natural

variations in the magnetic behavior of different types of ilmenites was tested on sample material from throughout the Colorado-Wyoming Kimberlite Province (Fig. 1). A rod type self-releasing electromagnet tapered to a point to create a "point source" magnetic field was utilized. Sample populations were separated electromagnetically in a series of runs in which amperage and resulting point source magnetic field strength (measured in cersted) were incrementally and progressively increased (Table 1 ). Each category $(A-J)$ corresponds to a standardized range of approximately 150 cersted in magnetic field strength as measured at the tip of the rod.

Initial testing was conducted on three suites of samples exhibiting maximm variation in chemistry in an attempt to quantify characteristic simple paramagnetic susceptibility (SPMS) behavior patterns (Vos, 1989). A picroilmenite suite was obtained from megacrysts from Colorado-Wyoming kimberlite occurrences, ferroilmenite (both groundmass and ore varieties) was collected from the Laramie Anorthosite complex and associated titaniferous magnetite-ferroilmenite ore bodies in Wyoming, and a manganoan ilmenite suite from stream sediment concentrate from the Guaniamo region of Venezuela was used. The picroilmenite suite was eventually expanded to include 3,600 grains from 19 colorado-Wyoming kimberlite occurrences. Four SPMS pattern groups evolved from this suite, and these relate to different kimberlite occurrences: Group I - Schaffer, Aultman and Ferris; Group 2 - Sloan, Moen, Nix and Chicken Park; Group 3 Iron Mountain District; and Group 4 - Estes Dike and Green Mountain (Fig. 1).

Cumulative SPMS histograph patterns are presented as 100 total count normalized data, thereby effectively ratioing each of the categorical values $(A-J)$ into relative percentages. Although significant overlap may exist in SPMS patterns, variable paramagnetic behavior generally reflects differences in bulk chemistry, valence states of major cations ( $\mathrm{Fe}^{2+}$, $\mathrm{Fe}^{3+}, \mathrm{Ti}^{4+}, \mathrm{Al}^{3+}, \mathrm{Mn}^{2+}$, and $\mathrm{Mg}^{2+}$, and structural position of those cations within the ilmenite structural-chemical lattice (Iindsley, 1976). Ferroilmenites are characterized by higher $\mathrm{FeO}$ and lower $\mathrm{MgO}$ and $\mathrm{Cr}_{2} \mathrm{O}_{3}$ than kimberlitic picroilmenites and have distinct SPMS behavior patterns. Their magnetic field strengths generally are greater than 1,000 to 1,100 cersted (category D) whereas picroilmenites typically have much lower field strengths (Fig. 2). Manganoilmenites also generally are less magnetic than ferroilmenites, but tend to be more magnetic than picroilmenites.

Differences in SPMS behavior within the four recognized ColoradoWyoming picroilmenite groups reflect variations in primary chemistry or subsequent alteration chemistry (Vos, 1989). Group 1 and 2 ilmenites generally contain higher amounts of $\mathrm{MgO}), \mathrm{Cr}_{2} \mathrm{O}_{3}$ and $\mathrm{Fe}_{2} \mathrm{O}_{3}$ than Group 3 ilmenites, and Group 2 ilmenites show maximum enrichment in $\mathrm{Cr}_{2} \mathrm{O}_{3}, \mathrm{TiO}_{2}$ and Mgo which accounts for their generally low SPMS values. Group 3 
ilmenites contain the highest total iron contents, which are reflected in their overall higher relative SPMS values. Group I ilmenites tend to have magnetic values similar to Group 2 ilmenites, which are lower than anticipated. A weaker magnetic susceptibility in these ilmenites probably is a function of pervasive severe alteration which produced nommagnetic secondary products such as rutile, goethite and leucoxene, and likely was accompanied by selective leaching of $\mathrm{Fe}^{2+}$ and(or) oxidation of $\mathrm{Fe}^{2+}$ to $\mathrm{Fe}^{3+}$. Some Group 2 ilmenites, especially from Chicken Park, exhibit a strong magnetic character due to the presence of abundant "exsolved" titanomagnetite lamellae. Group 4 ilmenites have SPMS values intermediate between Group 3 and Groups 1 and 2, and are characterized by high $\mathrm{TiO}_{2}$ and $\mathrm{MgO}$ and very low $\mathrm{Fe}_{2} \mathrm{O}_{3}$.

Picroilmenite Groups 1, 2 and 4 show relatively good magnetic discrimination from ferroilmenite (Group 5) and effective separation can be achieved at about 1,100, 1,400, and 1,200 oersted magnetic field strengths respectively (Fig. $3 \mathrm{a}, \mathrm{b}, \mathrm{d}$ ). Group 3 picroilmenite, with a broader range of SPMS values, can be less effectively separated from ferroilmenite, but a reasonable separation can be achieved at about 900 cersted magnetic field strengths (Fig. 3c). Separation would be considerably less effective if manganoilmenite were present (Fig. 2).

Based on these preliminary observations on Colorado-Wyoming kimberlite concentrate, it appears that the SPMS properties of ilmenites may be exploited in separating ferro- from picroilmenites in kimberlite exploration surveys, especially where concentrates are saturated with ferroilmenite. This technique could substantially reduce the amount of opaque oxide chemical analyses needed for effective detection of kimberlitic picroilmenite. However, care should be taken to carefully investigate the SPMS behavior of regionally indigenous ferro; mangano- and picroilmenites prior to determining the most effective applied magneticseparation field strength.

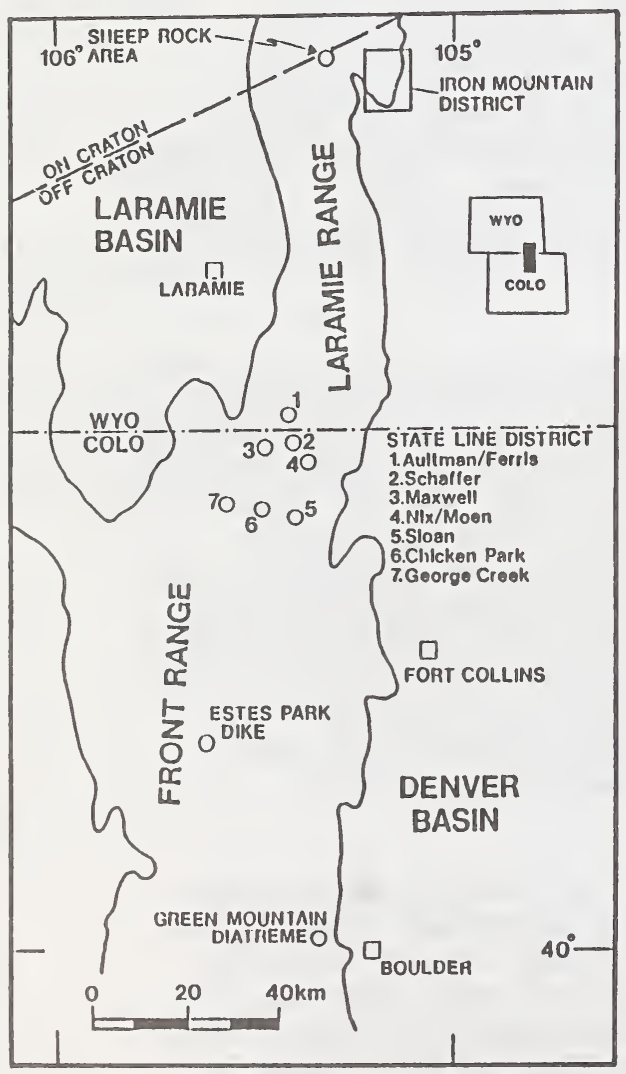

\section{REFERENCES}

Lindsley, D.H. (1976) The crystal chemistry and structure of oxide minerals as exemplified by the $\mathrm{Fe}-\mathrm{Ti}$ oxides. In $\mathrm{D}$. Rumble III, Ed., Oxide Minerals, Mineralogical society of America, Short Course Notes, v. 3, p. II-I60.

Vos, W.P. (1989) Kimberlite exploration, S. Laramie Range, Wyo. and magnetism, textures, and chemistry of Mg-ilmenite, $326 \mathrm{p}$. M.S. thesis, Colorado State University, Fort collins, colorado.

FIGURE 1. Iocation map of kimberlite occurrences in the coloradoWyoming Kimberlite Province. Front and Laramie Range area underlain by Precambrian crystalline rocks, Basin areas underlain by post-Devonian sedimentary rocks. On craton-off craton, line marks boundary between Archean and Proterozoic crustal rocks. 

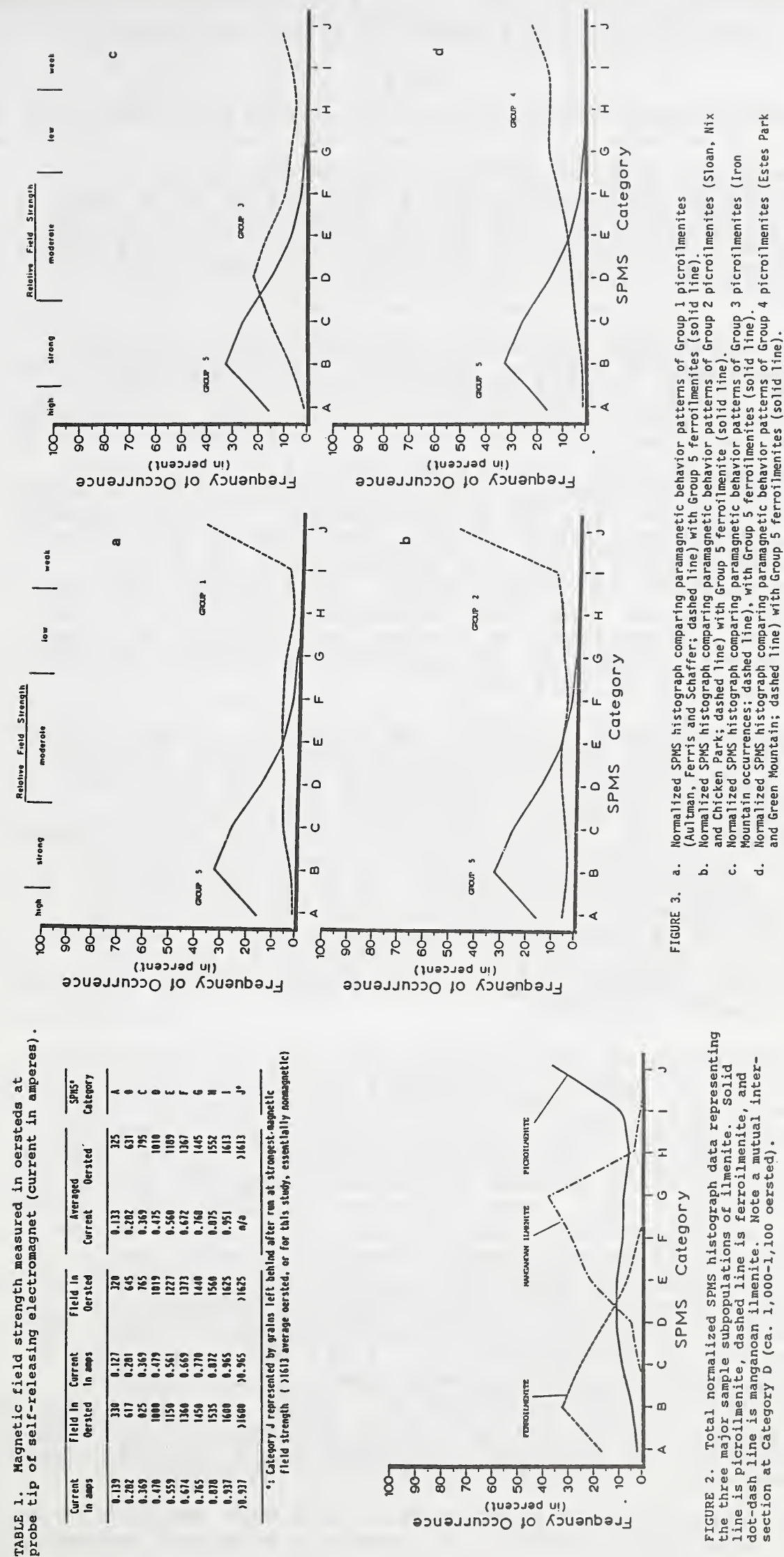